\title{
ATIVISMO JUDICIAL E A EFETIVAÇÃO DE DIREITOS NO SUPREMO TRIBUNAL FEDERAL: ANÁLISE DO JULGAMENTO DA ADPF 132 E DA ADI 4277
}

Liv Lessa Lima de Holanda*1

\begin{abstract}
Resumo: O Poder Judiciário tem desempenhado um papel central na vida institucional brasileira, tomando decisões históricas, que por vezes envolvem implementação de políticas públicas, efetivação de direitos fundamentais ou até escolhas morais em temas controvertidos. Foi para entender melhor esses acontecimentos que se decidiu estudar sobre judicialização e ativismo judicial neste artigo. Primeiramente, buscou-se traçar as linhas gerais sobre a matéria, definindo os fenômenos e, sobretudo, ressaltando as diferenças entre eles. Em seguida, procedeu-se à análise do julgamento da ADPF 132 e da ADI 4277, sobre a união estável homoafetiva, que recebeu fortes críticas por ter sido apontado como ativista.
\end{abstract}

Palavras-chave: Poder Judiciário; Judicialização; Ativismo Judicial; União Estável Homoafetiva.

\section{JUDICIAL ACTIVISM AND THE EFFECTIVENESS OF RIGHTS IN THE SUPREME FEDERAL COURT: ANALYSIS OF THE JUDGMENT OF ADPF 132 AND ADI 4277}

\begin{abstract}
Judiciary has played a central role in Brazilian institutional life, making historical decisions, which sometimes involve the implementation of public policies, the enforcement of fundamental rights, or even moral choices on controversial issues. It was to better understand these events that it was decided to study judicialization and judicial activism in this article. At first, we sought to draw the general lines about matter, defining the phenomena and, above all, highlighting the differences between them. Then, the judgment of ADPF 132 and ADI 4277 on the stable homoaffective union was analyzed, which was strongly criticized for being considered an activist.
\end{abstract}

Keywords: Judiciary; Judicialization; Judicial Activism; Homoaffective Union.

\footnotetext{
$1 *$ Graduada em Direito pela Universidade Federal de Alagoas - UFAL. Mestranda em Direito Público pela Universidade Federal de Alagoas - UFAL. Servidora Pública da Justiça Federal de Alagoas. Endereço postal: Avenida Doutor Antonio Gouveia, ${ }^{\circ}$ 317, apto 202, Pajuçara, Maceió/Alagoas, Cep.; 57030-170. E-mail: liv_lessa@msn.com
} 


\section{Introdução}

No período pós Segunda Guerra, verificou-se, na maior parte dos países ocidentais, um novo panorama Constitucional. Devido às atrocidades nazistas praticadas na guerra contra a raça humana, houve uma mobilização dos próprios países envolvidos para instituir nas constituições novos valores fundamentais, que obrigassem inclusive o Estado (VIANNA; BURGOS; SALLES, 2007, p. 39).

Neste cenário, também veio à tona o Estado do Bem-Estar Social (Welfare State), que trouxe a promulgação de direitos sociais com o intuito de diminuir as desigualdades entre classes (VIANNA; BURGOS; SALLES, 2007, p. 40).

É a partir deste momento, em que o Estado se preocupa em garantir as condições de sobrevivência da sociedade nas próprias Constituições, que o direito começa a ser colocado no centro da vida social e o Judiciário começa a ganhar mais espaço em detrimento do Executivo e do Legislativo.

No Brasil, no período pós-ditadura militar, a partir da promulgação da Constituição Federal de 1988, esse fenômeno fica mais evidente.

As novas formas de provocação do Judiciário pela sociedade civil organizada, assim como a criação dos juizados de pequenas causas são fatores que acabaram por promover uma maior aproximação do Judiciário com a população e por colocá-lo cada vez mais em evidência perante a sociedade (VIANNA; BURGOS; SALLES, 2007, p. 41).

Como resultado disso, o Poder Judiciário foi chamado para solucionar os mais diversos temas, iniciando-se assim uma fase de judicialização.

Destarte, não existe mais matéria que não possa ser levada a apreciação de um tribunal. Neste cenário, o Supremo Tribunal Federal é o grande protagonista, sendo levado a ele temas que versam desde a implementação de políticas públicas, efetivação de direitos fundamentais a escolhas morais.

Na análise de tais decisões, foi observado que os magistrados na busca por solucionar os diversos casos a eles submetidos, muitas vezes optavam por uma decisão criativa ou proativa, o que convencionou-se denominar de ativismo judicial.

Foi devido ao papel ativo que o STF tem desempenhado na vida institucional brasileira e à centralidade do judiciário na tomada de decisões sobre grandes questões nacionais, que se optou por escrever sobre esse tema. 


\section{ATIVISMO JUDICIAL E A EFETIVAÇÃO DE DIREITOS NO SUPREMO TRIBUNAL FEDERAL: ANÁLISE DO JULGAMENTO DA ADPF 132 E DA ADI 4277}

Escolheu-se abordar o julgamento da ADPF 132 e ADI 4277 porque, além de ser um caso emblemático e de grande repercussão nacional, houve fortes críticas no sentido de que o STF havia adotado uma postura ativista, que desestabilizava a democracia, em virtude de ter ele implementado uma nova forma de união estável diferente da preconizada na Constituição Federal.

Para organizar esse percurso, este artigo foi dividido em duas partes.

Em um primeiro momento, buscou-se traçar as linhas gerais do ativismo judicial, destacando o surgimento da expressão, a diferença entre ativismo e judicialização e as várias acepções do termo ativismo, além das críticas a essa postura. Para tanto, buscamos supedâneo em doutrinadores consagrados, como Luís Roberto Barroso, Anderson Teixeira e Werneck Vianna.

Em um segundo momento, refletimos sobre o percurso da união homoafetiva no judiciário brasileiro, para só então nos determos na análise do julgamento da ADPF 132 e ADI 4277, na qual se pretendeu discutir, com base nos ensinamentos de Lênio Streck, Marianna Chagas e Jorge Luiz Ribeiro de Medeiros, em que medida tal decisão pode ser considerada ativista.

Desse modo, por meio da revisão bibliográfica, com a utilização do método descritivo, pretende-se discorrer sobre a matéria.

\section{Ativismo judicial: questões preliminares}

O ativismo judicial, cuja origem remonta à jurisprudência norte-americana, possuía natureza conservadora, em virtude de atuações proativas da Suprema Corte que acabaram por promover a segregação racial (Dred Scott v. Sanford, 1857) e a invalidação de leis sociais (Lochner v. New York, 1905) (BARROSO, 2017).

Nesse último caso, a Suprema Corte dos Estados Unidos entendeu que o princípio da liberdade contratual estava implícito na noção de devido processo legal (due process of law) consagrado na Constituição norte-americana, o que a fez declarar inconstitucional uma lei do estado de Nova Iorque que limitava em 60 horas a jornada de trabalho semanal dos padeiros, alegando ser irrazoável, inconstitucional e arbitrária (TEIXEIRA, 2012).

A partir da década de 50, a situação começou a se inverter e a Suprema Corte dos Estados Unidos passou a produzir jurisprudência progressista em matérias de direitos fundamentais. Podemos citar os casos Brown v. Board of Education, 1954; Miranda v. Arizona, 
1966; Richardson v. Frontiero, 1973; Griswold v. Connecticut, 1965 e Roe v. Wade, 1973 (BARROSO, 2017).

Apesar de o primeiro caso de ativismo judicial relatado datar de 1857 (Dred Scott v. Sanford), foi somente em 1947, quando o historiador e crítico social Arthur M. Schlesinger Jr. escreveu uma matéria para a revista Fortune, intitulada The Supreme Court:1947, que a locução cunhada nos Estados Unidos “judicial activism” se popularizou não apenas no vocabulário jurídico, mas especialmente no político e popular (TEIXEIRA, 2012).

Na matéria, o historiador traçou o perfil dos juízes que compunham a Suprema Corte e os dividiu em dois grupos, denominando de ativistas judiciais os juízes Hugo Black, Willian O. Douglas, Frank Murphy e Wiley Rutledge, referindo-se à capacidade deles de desempenhar um papel afirmativo na promoção do bem-estar social. Por outro lado, os juízes Felix Frankfurter, Harold Burton e Robert H. Jackson ficaram conhecidos como "campeões do autocomedimento" (champions of self-restraint), por entenderem que o Judiciário não deve ir além dos limites previstos na legislação estadunidense. Em uma posição intermediária, o presidente da Suprema Corte naquele ano, Frederick M. Vinson, e o juiz Stanley F. Reed não seriam plenamente caracterizáveis como de um ou outro lado (TEIXEIRA, 2012).

Em virtude de uma reação conservadora, a expressão ativismo judicial, ganhou nos EUA uma conotação negativa, sendo equiparada ao exercício impróprio do poder judicial (CHAVES, 2017).

\section{1 Ativismo judicial no Brasil}

Se nos Estados Unidos o ativismo judicial possui longa data e continua gerando polêmica, no Brasil esse fenômeno é relativamente recente, tendo ganhado expressão com a promulgação da Constituição de 1988, que atribuiu ao magistrado uma série de prerrogativas, impulsionando-o a uma atuação mais presente na sociedade.

Diversos fatores podem ser considerados responsáveis para uma atuação do judiciário mais proativa no Brasil.

Dentre eles, o professor Anderson Teixeira (2012) elenca os milhares de casos em que se faz necessário assegurar direitos fundamentais que não encontram previsão legal em condições de lhes dar regulamentação e a ampla possibilidade de utilização do controle abstrato de constitucionalidade, após a Emenda Constitucional nº 16 de 1965, que fez com que o debate 


\section{ATIVISMO JUDICIAL E A EFETIVAÇÃO DE DIREITOS NO SUPREMO TRIBUNAL FEDERAL: ANÁLISE DO JULGAMENTO DA ADPF 132 E DA ADI 4277}

sobre a constitucionalidade das leis, que antes se cingia ao âmbito político, concentrasse-se cada vez mais nas instâncias ordinárias.

Em entrevista concedida por Teori Zavaski ao Jornal GGN, o saudoso ministro do STF, corroborando o entendimento acima, explicou que há dois espaços importantes para o ativismo judicial no Brasil.

O primeiro deles é a insuficiência da atividade legislativa, que pode se dá por várias causas, uma delas porque o legislador não trabalha com o futuro. O segundo é o fato de a Constituição Brasileira ter conferido ao Judiciário mecanismos importantes para preencher esses vazios, como a aplicação dos princípios gerais do direito e da analogia. Além disso, o mandado de injunção e a Ação Direta de Inconstitucionalidade (ADI), para preencher as lacunas do legislador (NASSIF, 2017).

Nessa linha de raciocínio, Luís Roberto Barroso é de opinião que o Judiciário no Brasil recente tem assumido posições bastante ativistas.

O doutrinador cita alguns exemplos: a) o julgamento da fidelidade partidária, em que o STF, em nome do princípio democrático, declarou que a vaga no Congresso pertence ao partido político, criando assim uma nova hipótese de perda de mandato parlamentar, além das previstas na Constituição; b) a extensão da vedação do nepotismo aos Poderes Legislativo e Executivo, por meio de expedição de súmula vinculante, após o julgamento de um único caso, extraindo, em nome dos princípios da moralidade e impessoalidade, uma vedação que não estava expressa na Constituição ou na norma infraconstitucional; c) o caso da verticalização, em que o STF declarou a inconstitucionalidade da aplicação das novas regras sobre coligações eleitorais à eleição que se realizaria em menos de um ano da sua aprovação; d) a distribuição de medicamentos e determinação de terapias mediante decisão judicial, sobretudo no âmbito das Justiças estadual e federal em todo o país, onde multiplicam-se as decisões que condenam a União, o Estado ou o Município, por vezes, solidariamente, a custear medicamentos e terapias que não constam nas listas e protocolos do Ministério da Saúde ou das Secretarias Estaduais e municipais (BARROSO, 2017).

Além desses mencionados por Barroso, ao longo desses anos, muitos outros julgamentos ficaram marcados por uma postura do judiciário considerada ativista, lembramos aqui as decisões proferidas nos casos da demarcação da reserva Raposa Serra do Sol, em que houve a imposição de 19 medidas para a implementação da demarcação; do direito de greve no 
serviço público, do uso restrito das algemas e do reconhecimento da união estável homoafetiva, que mais adiante será analisada neste artigo, dentre outros.

\subsection{Ativismo judicial versus judicialização}

Antes de aprofundarmos o estudo sobre o ativismo judicial, convém tecer alguns comentários sobre a judicialização, bem como ressaltar as diferenças entre esses dois fenômenos.

A judicialização significa que algumas questões de grande alcance político ou social estão sendo decididas por juízes e tribunais, em detrimento das instâncias políticas tradicionais, representadas pelo Poder Legislativo e o Poder Executivo, fortalecendo assim cada vez mais o Poder Judiciário (BARROSO, 2017).

Barroso (2017) identifica três causas que impulsionaram o fenômeno da judicialização no Brasil: a primeira delas foi a redemocratização do país, que fortaleceu e expandiu o Poder Judiciário, bem como aumentou a demanda por Justiça na sociedade brasileira; a segunda foi a constitucionalização abrangente, que trouxe para a Constituição diversas matérias antes deixadas para a legislação infraconstitucional; a terceira é o sistema brasileiro de controle de constitucionalidade, um dos mais abrangentes do mundo, combina aspectos de dois sistemas diversos: o americano e o europeu.

Seguindo essa mesma linha de raciocínio, Werneck Wianna sustenta que a judicialização da política e das relações sociais foram propiciadas pelo modelo institucional adotado pelo Estado, que possibilitou um maior número de atores na propositura das ADIs e a criação dos Juizados de Pequenas Causas, aproximando a sociedade civil do judiciário (VIANNA; BURGOS; SALLES, 2007, p. 41).

Embora muitos confundam, é importante frisar que judicialização e ativismo judicial são fenômenos distintos.

Para Barroso (2017), a diferença entre eles reside no fato de que a judicialização não decorre de uma opção ideológica, filosófica ou metodológica do Judiciário, mas é um fato, uma circunstância que decorre do modelo constitucional que se adotou. Enquanto o ativismo é uma atitude do julgador, uma escolha.

Sobre a questão, Lênio Streck (2017) afirma que o ativismo é sempre ruim para a democracia, uma vez que resulta de comportamentos e visões pessoais de juízes e tribunais. 


\title{
ATIVISMO JUDICIAL E A EFETIVAÇÃO DE DIREITOS NO SUPREMO TRIBUNAL FEDERAL: ANÁLISE DO JULGAMENTO DA ADPF 132 E DA ADI 4277
}

Quanto à judicialização, pode ser boa ou ruim, dependendo dos níveis de intensidade em que é verificada.

\subsection{Ativismo judicial: buscando uma definição}

Diversos autores tentaram definir o ativismo, havendo na doutrina quem aplaudisse essa postura do judiciário e quem a criticasse.

Do ponto de vista do professor Anderson Vichinkeski Teixeira (2012), o ativismo judicial, um dos sintomas mais flagrantes da sociedade pós-moderna, representa a insuficiência do Estado em atender aos anseios de sua população, bem como buscar a realização dos objetivos que lhe foram postos.

A advogada Marianna Chaves (2017) entende que o ativismo judicial se trata de uma maneira proativa de interpretar a Constituição, estendendo o seu alcance e sentido. A autora pondera que ele não pode ser exacerbado, devendo ser utilizado com prudência, moderação e em última circunstância.

De modo semelhante, Luís Roberto Barroso (2017) assevera que o ativismo é uma atitude do juiz, que escolhe um modo específico e proativo de interpretar a Constituição, expandindo o seu sentido e alcance. "Normalmente, ele se instala em situações de retração do Poder Legislativo, de certo deslocamento entre a classe política e a sociedade civil, impedindo que determinadas demandas sejam atendidas de maneira efetiva”.

Explica o doutrinador que:

\begin{abstract}
A ideia de ativismo judicial está associada a uma participação mais ampla e intensa do Judiciário na concretização dos valores e fins constitucionais, com maior interferência no espaço de atuação dos outros dois Poderes. A postura ativista se manifesta por meio de diferentes condutas, que incluem: (i) a aplicação direta da Constituição a situações não expressamente contempladas em seu texto e independentemente de manifestação do legislador ordinário; (ii) a declaração de inconstitucionalidade de atos normativos emanados do legislador, com base em critérios menos rígidos que os de patente e ostensiva violação da Constituição; (iii) a imposição de condutas ou de abstenções ao Poder Público, notadamente em matéria de políticas públicas (BARROSO, 2017).
\end{abstract}

Barroso (2017) escreve que o ativismo judicial tem seus aspectos positivos e negativos. Se por um lado o Judiciário está atendendo a demandas da sociedade que não puderam ser satisfeitas pelo parlamento, em temas como greve no serviço público, eliminação do nepotismo 
ou regras eleitorais, por outro exibe as dificuldades enfrentadas pelo Poder Legislativo e afasta ainda mais a classe política da sociedade civil.

De modo contrário, o jurista Lênio Luiz Streck (2017) pensa que o ativismo sempre é ruim para a democracia, porque decorre de comportamentos de visões pessoais de juízes e tribunais. Compara a uma linguagem privada construída à margem da linguagem pública.

Por último, o professor Marco Paulo Veríssimo (2008, p. 409) sustenta que um judiciário ativista é aquele que não se constrange em exercer competências de revisão cada vez mais amplas, quer incidentes sobre a política parlamentar (especialmente via controle de constitucionalidade), quer incidentes sobre as políticas de ação social do governo (via controle da administração pública).

No entanto, nem sempre o ativismo judicial preponderou no Brasil. Até o advento da Constituição de 1988, o judiciário se pautava pela autocontenção judicial, conduta pela qual o judiciário procura reduzir sua interferência nas ações dos outros poderes.

Nos dizeres de Luís Roberto Barroso (2017):

Por essa linha, juízes e tribunais (i) evitam aplicar diretamente a Constituição a situações que não estejam no seu âmbito de incidência expressa, aguardando o pronunciamento do legislador ordinário; (ii) utilizam critérios rígidos e conservadores para a declaração de inconstitucionalidade de leis e atos normativos; e (iii) abstêm-se de interferir na definição das políticas públicas.

Como se pode perceber, ativismo e autocontenção judicial são posições antagônicas. Enquanto a primeira procura extrair o máximo das potencialidades do texto constitucional sem invadir o campo de atuação do legislador, a segunda restringe o espaço de incidência da Constituição em favor das instâncias tipicamente políticas (BARROSO, 2017).

\section{Percurso da união homoafetiva no Judiciário brasileiro}

Conforme visto acima, o ativismo judicial e a judicialização são fenômenos presentes no judiciário brasileiro, que trouxeram modificações ao cenário nacional.

Na abordagem até aqui realizada, permitiu-se o conhecimento sobre esses temas a partir de uma perspectiva teórica, necessária para fixar os parâmetros doutrinários em que o assunto se encontra inserido. A partir deste momento, o tema será analisado com base em uma decisão concreta proferida pelo Supremo Tribunal Federal. 


\section{ATIVISMO JUDICIAL E A EFETIVAÇÃO DE DIREITOS NO SUPREMO TRIBUNAL FEDERAL: ANÁLISE DO JULGAMENTO DA ADPF 132 E DA ADI 4277}

O caso escolhido para a referida análise foi o julgamento da ADPF 132 e ADI 4277, realizado em maio de 2011, em que o STF reconheceu a união estável entre pessoas do mesmo sexo, equiparando-a a união estável heterossexual.

As razões para essa escolha se deram porque, além de representar um caso emblemático e de grande repercussão nacional, a decisão sofreu fortes críticas sob o argumento de que o STF teria adotado uma postura ativista, que desestabilizava a democracia, em virtude de ter ele implementado uma nova forma de união estável diferente da preconizada na Constituição Federal.

Antes, porém, de se analisar pormenorizadamente o caso escolhido, faz-se necessário relembrar de que forma o debate sobre a união homoafetiva chegou até o judiciário e que tratamento vinha recebendo dos juízes e tribunais brasileiros antes do julgamento que a reconheceu como união estável no Supremo Tribunal Federal.

Como já estudado neste artigo, o fenômeno da judicialização permitiu a chegada dos mais variados debates sociais e políticos no Poder Judiciário, não ficando de fora a questão da união homoafetiva.

A falta de regulamentação jurídica no Brasil em relação ao tema fez com que as pessoas batessem a porta do judiciário para pleitear o reconhecimento das relações que nasciam a partir da família homoafetiva.

Em um primeiro momento, a jurisprudência costumava reconhecer as uniões homoafetivas como meras sociedades de fato, conferindo-lhes apenas efeitos patrimoniais e negando-lhes a relação afetiva existente característica de uma família.

Nesse sentido, invocava-se a súmula 380 do STF: "comprovada a existência de sociedade de fato entre os concubinos, é cabível a sua dissolução judicial, com a partilha do patrimônio adquirido pelo esforço comum.”

Contudo, esse posicionamento começou a mudar a partir de 1999, quando a justiça gaúcha firmou a competência dos juizados especializados de família para apreciar as uniões homossexuais.

Relações homossexuais - Competência para julgamento de separação de sociedade de fato dos casais formados por pessoas do mesmo sexo. Em se tratando de situações que envolvem relações de afeto, mostra-se competente para o julgamento de causa uma das varas de família à semelhança das separações ocorridas entre casais heterossexuais. Agravo provido (TJRS - AI nº 599075496, 8 a C. Cível, Rel. Des. Breno Moreira Mussi). 
Também é do Rio Grande do Sul decisão de 2001 que deferiu o direito à herança ao parceiro homossexual. A partir desse precedente, decisões no mesmo sentido começaram a surgir em todo o país.

União homossexual - Reconhecimento - Partilha do Patrimônio - Meação Paradigma. Não se permite mais o farisaísmo de desconhecer a existência de uniões entre pessoas do mesmo sexo e a produção de efeitos jurídicos derivados dessas relações homoafetivas. Embora permeadas de preconceitos, são realidades que o Judiciário não pode ignorar, mesmo em sua natural atividade retardatária. Nelas remanescem consequências semelhantes às que vigoram nas relações de afeto, buscando-se sempre a aplicação da analogia e dos princípios gerais do direito, relevados sempre os princípios constitucionais da dignidade humana e da igualdade. Desta forma, o patrimônio havido na constância do relacionamento deve ser partilhado como na união estável, paradigma supletiva onde se debruça a melhor hermenêutica. Apelação provida, em parte, por maioria, para assegurar a divisão do acervo entre os parceiros (TJRS - AC ñ 70001388982, $7^{\text {a }}$ C. Cível, Rel. Des. José Carlos Teixeira Giorgis).

Na esfera patrimonial, os homossexuais conseguiram conquistar direitos no tocante à inclusão do parceiro no plano de saúde, à pensão por morte e à meação dos bens como na união estável em caso de separação do casal, conforme julgados colacionados a seguir:

PROCESSO CIVIL E CIVIL - PREQUESTIONAMENTO - AUSÊNCIA SÚMULA 282/STF - UNIÃO HOMOAFETIVA - INSCRIÇÃO DE PARCEIRO EM PLANO DE ASSISTÊNCIA MÉDICA - POSSIBILIDADE - DIVERGÊNCIA JURISPRUDENCIAL NÃO-CONFIGURADA. 282. (...) A relação homoafetiva gera direitos e, analogicamente à união estável, permite a inclusão do companheiro dependente em plano de assistência médica.- O homossexual não é cidadão de segunda categoria. A opção ou condição sexual não diminui direitos e, muito menos, a dignidade da pessoa humana (STJ - REsp nº 238715/RS, $3^{\text {a }}$ Turma, Rel. Min. Humberto Gomes de Barros).

PREVIDENCIÁRIO. PENSÃO POR MORTE DE PARCEIRO HOMOSSEXUAL. POSSIBILIDADE. COMPROVAÇÃO UNIÃO ESTÁVEL PARA FINS PREVIDENCIÁRIOS. CASAL SEPARADO. PAGAMENTO DE PENSÃO ALIMENTÍCIA. DEPENDÊNCIA ECONÔMICA PRESUMIDA. CORREÇÃO MONETÁRIA. JUROS DE MORA. HONORÁRIOS ADVOCATÍCIOS.1.É possível a comprovação de união estável entre pessoas do mesmo sexo para fins de percepção 


\title{
ATIVISMO JUDICIAL E A EFETIVAÇÃO DE DIREITOS NO SUPREMO TRIBUNAL FEDERAL: ANÁLISE DO JULGAMENTO DA ADPF 132 E DA ADI 4277
}

do benefício de pensão por morte, consoante precedentes dessa Corte.2. Se o cônjuge divorciado ou separado recebia pensão alimentícia do de cujus, a dependência econômica é presumida, fulcro no artigo 76 , § $2^{\circ}$, da Lei n. ${ }^{\circ} 8.213 / 91.76 \S 2^{\circ} 8.2133$. Preenchidos os requisitos contidos no art. 74 da Lei 8.213/91, é de ser concedido o benefício de pensão por morte, a partir da DER (TRF 4 - APELREEX 53659/RS, Turma suplementar, Rel. Des. Federal Luís Alberto D Azevedo Aurvalle).

APELAÇÃO. UNIÃO ESTÁVEL HOMOAFETIVA. COMPROVAÇÃO. PARTILHA. LIQUIDAÇÃO DE SENTENÇA. Caso em que restou amplamente demonstrada a existência, entre apelante e apelada, de relacionamento afetivo, íntimo, e sexual, repleto de amor, carinho e afeto, com comunhão de vida, de interesses e de patrimônio, com estabilidade e publicidade, e com clara intenção de constituir família. Necessidade de declaração da existência de união estável, com a consequente partilha dos bens onerosamente amealhados no período (TJRS - AC nº 70040469082, $8^{\text {a }}$ câmara cível, Rel. Des. Rui Portanova).

Passou também a jurisprudência a admitir a adoção por pares homossexuais.

\begin{abstract}
Adoção. Casal formado por duas pessoas do mesmo sexo. Possibilidade. Reconhecida como entidade familiar, merecedora da proteção estatal, a união formada por pessoas do mesmo sexo, com características de duração, publicidade, continuidade e intenção de constituir família, decorrência inafastável é a possibilidade de que seus componentes possam adotar. Os estudos por casais homossexuais, mais importando a qualidade do vínculo e do afeto que permeia o meio familiar em que serão inseridas e que as liga aos seus cuidadores. É hora de abandonar de vez preconceitos e atitudes hipócritas desprovidas de base científica, adotando-se uma postura de firma defesa da absoluta prioridade de que constitucionalmente é assegurada aos direitos das crianças e dos adolescentes (art. 227 da Constituição Federal). Caso em que o laudo especializado comprova o saudável vínculo existente entre as crianças e as adotantes. Negaram provimento. Unânime (TJRS - AC nº 70013801592, 7ª Câmara Cível, Rel. Des. Luiz Felipe Brasil Santos).
\end{abstract}

Embora, ao longo dos últimos anos, nossa jurisprudência pátria tenha avançado no sentido de conferir direitos às uniões homoafetivas, a amplitude das decisões dos casos observados tinha eficácia apenas inter partes, limitando-se àqueles que figuravam no caso concreto. Assim, o reconhecimento da união entre pessoas do mesmo sexo como entidade familiar somente foi chancelada pelo Supremo Tribunal Federal.

\subsection{0 julgamento da ADPF 132 e da ADI 4277 à luz do ativismo judicial}

O julgamento do STF se deu em virtude da Arguição de Descumprimento de Preceito Fundamental (ADPF) nº 132 e da Ação Direta de Inconstitucionalidade (ADI) no 4277. 
A primeira foi apresentada em 25 de fevereiro de 2008, de autoria do Governador do Rio de Janeiro, Sérgio Cabral, visando especialmente que a Suprema Corte interpretasse, conforme a Constituição, o Estatuto dos Servidores Civis do Estado do Rio de Janeiro, aplicando-se analogicamente o art. 1723 do Código Civil brasileiro às uniões homossexuais, de modo que servidores estaduais homossexuais, conviventes em relações estáveis, também pudessem usufruir dos benefícios concedidos aos servidores unidos por laços heterossexuais.

A segunda, proposta pela Procuradoria Geral da República, em 02 de julho de 2009, objetivava o reconhecimento, no Brasil, da união entre pessoas do mesmo sexo como entidade familiar, e que os mesmos direitos e deveres dos companheiros das uniões estáveis fossem estendidos aos companheiros nas uniões homossexuais.

Todos os 10 ministros votantes no julgamento da ADPF 132 e da ADI 4277 manifestaram-se pela procedência das respectivas ações constitucionais, reconhecendo a união homossexual como entidade familiar.

No entanto, o resultado do julgamento recebeu duras críticas no meio jurídico no sentido de que o STF teria adotado uma postura ativista, afrontando o princípio da separação dos poderes e usurpando o papel do legislador.

A partir dessa polêmica, os estudiosos sobre o tema se dividiram para atacar ou defender a decisão.

Do ponto de vista de Marianna Chaves (2017), no julgamento da ADPF 132 e ADI 4277, o eventual ativismo judicial se justificou pela absoluta omissão do Legislativo em relação às questões concernentes à homoafetividade. Lembrou que existem diversos projetos de Lei que versam sobre as uniões homoafetivas de meados da década de 90, como o PL 1.151/95, PL 5.252/2001, PL 6.874/06, PL 4.914/2009 e mais recentemente o estatuto da diversidade sexual, que encontram entraves nas comissões formadas por parlamentares fundamentalistas, especialmente de viés religioso.

Ao contrário de Marianna Chaves, Lênio Streck se destaca como um crítico ferrenho ao ativismo judicial.

Em artigo que escreveu para a Revista dos Estudos Constitucionais, Hermenêutica e Teoria do Direito, sustenta as razões pelas quais discorda dos fundamentos da ADPF 138 (recebida pelo STF como ADI 4277), as quais podem ser sintetizadas da seguinte forma: 1.0 reconhecimento como entidade familiar das relações entre pessoas do mesmo sexo dependeria de emenda constitucional ou de projeto de lei, conforme, segundo o autor, teria ocorrido na 


\section{ATIVISMO JUDICIAL E A EFETIVAÇÃO DE DIREITOS NO SUPREMO TRIBUNAL FEDERAL: ANÁLISE DO JULGAMENTO DA ADPF 132 E DA ADI 4277}

Espanha; 2. o reconhecimento de relações homoafetivas pela jurisprudência do STF estaria incorrendo em "terceiro turno" no processo constituinte, caracterizando "um nítido excesso do poder judiciário no sentido de romper com o texto da Constituição”; 3. esse reconhecimento incorreria em um indevido ativismo judicial, perigoso e nocivo para a democracia, na medida em que exerceria uma função típica do poder legislativo; e 4. o entendimento da inadequação constitucional de uma união estável estritamente heterossexual estaria, em certa medida, resgatando a ideia (superada) da possibilidade de normas constitucionais inconstitucionais (STRECK, 2009).

Expõe o professor que “o judiciário pode intervir, e deve, sempre que estiver em jogo uma questão de princípio. Mas não cabe a este poder exarar decisões que manifestem preferências pessoais de seus membros ou de uma parcela da sociedade” (STRECK, 2009, p. 79).

Conclui que a questão da união estável homoafetiva não poderia ser determinada por um tribunal, pois seria necessária uma discussão mais ampla, que envolvesse todos os seguimentos da sociedade (STRECK, 2009, p. 80).

Com a devida vênia, divergimos do entendimento acima. O professor Jorge Luiz Ribeiro de Medeiros, cuja posição veremos a seguir, parece ter a opinião mais coerente sobre o tema, sendo a ela que nos filiamos.

O professor discorda que a interpretação que reconhece as relações homoafetivas e as equipara a união estável tenha rompido com o texto constitucional ou partido da ideia de normas constitucionais inconstitucionais. A decisão sobre a união estável homoafetiva decorre de uma interpretação unitária da Constituição, a partir do reconhecimento de direitos já existentes no plano constitucional. Não cria, portanto, direitos não previstos no ordenamento (MEDEIROS, 2017).

É desnecessária a previsão textual expressa para se reconhecer o direito ao relacionamento homoafetivo (MEDEIROS, 2017).

Além das entidades mencionadas expressamente pela Carta Magna, qualquer relação afetiva que preencha os requisitos da ostensividade, estabilidade e afetividade merece a proteção constitucional conferida à família. Assim já ensinava o professor Paulo Lôbo (2002):

No caput do art. 226 operou-se a mais radical transformação no tocante ao âmbito de vigência da tutela constitucional à família. Não há qualquer referência a determinado tipo de família, como ocorreu com as constituições brasileiras anteriores. Ao suprimir a locução “constituída pelo casamento” (art. 175 da Constituição de 1967-69), sem 
substituí-la por qualquer outra, pôs sob a tutela constitucional “a família”, ou seja, qualquer família. A cláusula de exclusão desapareceu. O fato de, em seus parágrafos, referir a tipos determinados, para atribuir-lhes certas consequências jurídicas, não significa que reinstituiu a cláusula de exclusão, como se ali estivesse a locução “a família, constituída pelo casamento, pela união estável ou pela comunidade formada por qualquer dos pais e seus filhos”. A interpretação de uma norma ampla não pode suprimir de seus efeitos situações e tipos comuns, restringindo direitos subjetivos. (...) Os tipos de entidades familiares explicitados nos parágrafos do art. 226 da Constituição são meramente exemplificativos, sem embargo de serem os mais comuns, por isso mesmo merecendo referência expressa. As demais entidades familiares são tipos implícitos incluídos no âmbito de abrangência do conceito amplo e indeterminado de família indicado no caput. Como todo conceito indeterminado, depende de concretização dos tipos, na experiência da vida, conduzindo à tipicidade aberta, dotada de ductilidade e adaptabilidade.

A superação da ideia de que seria necessária uma explicitação de formas de entidades familiares para que fossem dignas de tratamento jurídico, sustentada por Paulo Lôbo, dialoga com a visão de Dworkin.

Para o filósofo do direito norte-americano, a ideia de uma distinção entre direitos enumerados, ou seja, previstos expressamente, e direitos não enumerados, não expressos de maneira clara, é falsa, sendo desnecessária a enumeração ou explicitação em textos normativos para que haja o efetivo reconhecimento dos direitos (DWORKIN, 1992, p. 386).

Nas palavras de Dworkin (1992, p. 386-387):

A distinção que eu suponho estar discutindo, entre direitos enumerados e direitos não enumerados, é apenas outra simples questão de equívoco semântico. Constitucionalistas usam o termo “direitos não-enumerados” como um coletivo para um conjunto particular de direitos constitucionais reconhecidos ou controversos, incluindo o direito de viajar; o direito de associação; e o direito e privacidade do qual deriva o direito ao aborto, se é que esse direito existe. Eles consideram essa classificação como estabelecedora de uma importante distinção estrutural, como os termos “enumerados” e “não-enumerados” obviamente sugerem. Se os direitos e garantias individuais enumeram apenas alguns dos direitos necessários para uma sociedade de igual consideração e liberdade básica, e deixa outros direitos sem menção, então os juízes têm apenas o poder de afirmar os direitos realmente enumerados (...) Então a distinção entre direitos numerados e direitos nãoenumerados é amplamente entendida como condutora a um importante tema constitucional: A questão de saber “se” e “quando” as cortes tem autoridade de afirmar 
direitos que não estejam efetivamente enumerados na Constituição como direitos constitucionais genuínos. Eu entendo que tal questão é ininteligível, como eu disse no começo, porque essa distinção que presumidamente existe, não faz sentido.

O professor Jorge Luiz Ribeiro de Medeiros (2017) ainda argumenta que o STF, no julgamento da ADPF 132 e da ADI 4277, apenas interpretou a Constituição de modo a preservar a sua unidade e a sua maior efetividade.

Sobre os princípios da unidade da constituição e da interpretação efetiva, o mestre Canotilho (2003, p. 1223-1224) orienta:

O princípio da unidade da constituição ganha relevo autônomo como princípio interpretativo quando com ele se quer significar que a constituição deve ser interpretada de forma a evitar contradições entre as suas normas[...] princípio designado por princípio da eficiência ou princípio da interpretação efectiva, pode ser formulado da seguinte maneira: a uma norma constitucional deve ser atribuído o sentido que maior eficácia lhe dê. É um princípio operativo em relação a todas e quaisquer normas constitucionais, e embora a sua origem esteja ligada à tese da actualidade das normas programáticas, é hoje sobretudo invocado no âmbito dos direitos fundamentais.

Conclui o professor Jorge Luiz Ribeiro de Medeiros (2017) que, embora não enumerada, a entidade familiar formada pela união estável homossexual está presente em nossa Constituição. Esse reconhecimento já existe em decorrência de uma interpretação adequada, voltada para os princípios da dignidade, igualdade, liberdade e pluralidade, presentes em nosso ordenamento.

\section{Considerações finais}

A judicialização e o ativismo judicial são traços marcantes no atual cenário jurídico brasileiro.

A judicialização decorre do modelo de Constituição analítica e do sistema de controle de constitucionalidade abrangente adotado no Brasil.

O ativismo judicial, por sua vez, expressa uma postura do intérprete, um modo proativo de interpretar a Constituição, que se justifica como um mecanismo de contorno do processo político majoritário quando ele se encontra inerte. 
Acreditamos que o ativismo judicial no Brasil se mostra positivo, visto que tem sido uma forma de se efetivar os direitos fundamentais previstos na Constituição quando os poderes legislativo e executivo descumprem as suas funções.

Por outro lado, ele deve ser usado com parcimônia, moderação e em ultima ratio, de modo a não afrontar a democracia e o princípio da separação dos poderes.

Frise-se que o ativismo judicial não é a solução para a crise de representatividade, legitimidade e funcionalidade do Poder Legislativo, sendo imprescindível, para tanto, uma reforma política.

No tocante à decisão sobre a união estável homoafetiva, em que pesem as duras críticas, acreditamos que não houve ativismo judicial por parte do STF.

Nesse caso, o que a Suprema Corte fez foi interpretar a Constituição Federal de acordo com os princípios da unidade e da máxima efetividade, para reconhecer uma forma de família que, embora não mencionada expressamente na Carta Magna, existia e não podia ser alijada da proteção constitucional, com base nos princípios da liberdade, igualdade e dignidade da pessoa humana.

A família homoafetiva não precisa estar explicitamente prevista na Constituição Federal para ser reconhecida, uma vez que o rol do artigo 226 é meramente exemplificativo, ou seja, ele não limita todas as formas de família existentes às mencionadas expressamente, somente as cita por serem as mais comuns.

Como já dizia o professor Paulo Lôbo, qualquer relação afetiva que preencha os requisitos da ostensividade, estabilidade e afetividade merece a proteção constitucional conferida à família.

Em suma, ativismo judicial ou não, somos da opinião de que a decisão do STF foi correta, pois conferiu o status de família a milhões de brasileiros que batiam as portes do judiciário para ver reconhecidos seus direitos decorrentes das suas relações afetivas. Embora se argumente que a questão deveria ser resolvida pelo legislador, sabe-se que nem tão cedo isso aconteceria, haja vista os diversos projetos de lei no sentido de se reconhecer a união homoafetiva, criados desde meados da década de 90, que se encontravam emperrados. 


\section{Referências}

BARROSO, Luís Roberto. Judicialização, ativismo judicial e legitimidade democrática. Disponível em: <https://www.conjur.com.br/2008-dez22/judicializacao_ativismo_legitimidade_democratica>. Acesso em 20 dez. 2017.

CANOTILHO, J. J. Gomes. Direito Constitucional e Teoria da Constituição. 7. ed. Coimbra: Almedia, 2003.

CHAVES, Marianna. O julgamento da ADPF 132 e da ADI 4277 e seus reflexos na seara do casamento civil. Disponível em: <https://arpen-sp.jusbrasil.com.br/noticias/2978105/artigo-ojulgamento-da-adpf-132-e-da-adi-4277-e-seus-reflexos-na-seara-do-casamento-civil> . Acesso em: 15/12/2017.

DWORKIN, Ronald. Unenumerated rights: Wheter and How Roe Should be Overruled. In.:University of Chicago Law Review. n. 59, 1992.

LÔBO, Paulo Luiz Netto. Entidades familiares constitucionalizadas: para além dos numerus clausus. Jus navigandi, Teresina, ano 7, n. 53, jan. 2002. Disponível em: $<$ https://jus.com.br/artigos/2552/entidades-familiares-constitucionalizadas>. Acesso em: 23 dez. 2017.

MEDEIROS, Jorge Luiz Ribeiro de. Interpretar a Constituição não é ativismo judicial. Disponível em: <https:/hiperficie.wordpress.com/2011/05/06/hermeneutica-ehomossexualidade-reconhecendo-a-diferenca/>. Acesso em 16. dez. 2017.

NASSIF, Luís. A aula de Teori Zavaski sobre o ativismo judicial. Disponível em: $<$ https://jornalggn.com.br/noticia/a-aula-de-teori-zavaski-sobre-o-ativismo-judicial>. Acesso em: 20/12/2017.

STRECK, Lenio Luiz. O que é ativismo? Disponível em: <http://www.osconstitucionalistas.com.br/o-que-e-ativismo>. Acesso em 18 dez. 2017.

STRECK, Lenio Luis. Ulisses e o canto das sereias: sobre ativismos judiciais e os perigos da instauração de um terceiro turno da constituinte. Revista dos Estudos Constitucionais, Hermenêutica e Teoria do Direito (RECHTD), v.1, n. 2, Unisinos, pp. 75-83, jul./dez. 2009.

TEIXEIRA, Anderson Vichinkeski. Ativismo judicial: nos limites entre racionalidade jurídica e decisão política. Revista Direito GV, São Paulo, vol. 8, n. 1, jan/jun 2012. Disponível em: $<$ http://www.scielo.br/scielo.php?pid=S1808-

24322012000100002\&script=sci_arttext>.Acesso em: 12/12/2017.

VERÍSSIMO, Marcos Paulo. A Constituição de 1988, vinte anos depois: Suprema Corte e ativismo judicial “à brasileira”. Revista Direito GV, n. 4, São Paulo, pp. 407-440, jul./dez., 2008. 
VIANNA, Luiz Werneck; BURGOS, Marcelo Baumann; SALLES, Paula Martins. Dezessete anos de judicialização da política. Tempo Social: Revista de sociologia da USP. v. 19, n. 2. São Paulo: USP, FFLCH, pp. 39-85, nov., 2007. 